\title{
Ou Testamentiese literatuur uit die Noordryk (Israel) - Die neerslag van noordelike tradisies in die Ou Testament
}

\author{
W S Boshoff \\ (Universiteit van Suid-Afrika)
}

\begin{abstract}
Old Testament literature from the Northern Kingdom (Israel): The presence of northern traditions in the Old Testament
\end{abstract}

The literature originating from the Northern Kingdom of Israel conveys an important message in terms of the theological themes in the Old Testament. Several of the earliest prophetic characters, such as Elijah, Elisha, Amos and Hosea, were all active in the Northern Kingdom. The political and religious situation of the Northern Kingdom created the context for these prophets, and other authors who shaped the thinking about God in old Israel. There writings can be found in the Pentateuch, Deuteronomy and the Deuteronomistic History, as well as in the books of Amos, Hosea and Deutero-Micha.

\section{INLEIDING}

Die Noordryk (Israel) word dikwels nie hoog geag as een van die bronne van die godsdiens van ou Israel nie. Trouens, op voetspoor van die negatiewe beoordeling in 1 en 2 Konings van al die konings van die Noordryk as goddeloos en sleg (vgl bv die beoordeling van Omri, 1 Kon 16:2526), is daar talle Bybellesers wat in sulke negatiewe terme oor die Noordryk in die algemeen dink. Ek het elders probeer aandui hoe tendensieus en soms inkonsekwent die geskiedskrywing oor die Noordryk in 1 en 2 Konings is (Boshoff 2000:19-35). Heel dikwels word na Jerusalem gekyk as die primêre sentrum van die teologie en godsdiens van ou Israel. Die stad was immers die kultiese sentrum en hoofstad van Juda en dit was die stad van Dawid, die beroemde koning en rykstigter. Die mate waarin hierdie opvattings oor Jerusalem histories en argeologies geregverdig kan word, is egter die tema vir ' $n$ afsonderlike studie.

In hierdie artikel wil ek aandui hoedat sekere van die heel belangrikste teologiese ontwikkelinge wat in die Ou Testament neerslag gevind het, hulle oorspronge in die Noordryk gehad het.

Van die bekendste literatuur met wortels in die Noordryk is die profetiese boeke Amos en Hosea. Dié twee boeke was nie alleen formatief vir die genre "profetiese boeke" in die Ou Testament nie. Hulle dien ook as ' $\mathrm{n}$ belangrike bron vir navorsing oor die godsdiensgeskiedenis van ou Israel. Amos en Hosea is egter nie die enigste literatuur wat in die Noordryk tot stand gekom het nie. Die ander literatuur het meestal fragmetaries, as deel van ander boeke, in die Ou Testament tereg gekom. 
Hulle oorsprong was egter onmiskenbaar Noordryks. Soos die meeste ander literatuur met Noordrykse wortels, is ook Amos en Hosea in die Suidryk verder bewerk. Dit het gebeur nadat Samaria in $721 \mathrm{vC}$ geval het en die Noordryk onder die Assiriese aanslag geswig en verdwyn het (Schoors 1998:95).

Ander literatuur wat in die Noordryk tot stand gekom het, is die Ebron (Elohis) van die Pentateug, die Elia- en Elisaverhaalsiklusse (in 1 en 2 Konings), ' $n$ deel van die boek Miga en ' $n$ vroeë "Deuteronomium"-dokument.

' $n$ Besondere Noordrykse dokument wat vanaf 1 Konings 12 dikwels vermeld word, is die annale van die konings van Israel (vgl 1 Kon 14:19, 15:31, 16:5, 16:14, 16:20, 16:27, 22:39). Dit was, tesame met die annale van die konings van Juda (vgl 1 Kon 14:29, 15:7, 15:23, $22: 46)$ klaarblyklik van die kernbronne vir die geskiedskrywers van die laaste deel van die Deuteronomistiese Geskiedwerk. Dit is die geskiedenis van die twee ryke, Israel en Juda.

W Vosloo het veral in sy lesings oor die boek Hosea, maar ook in ander geskrifte heelwat klem laat val op die belangrikheid en uniekheid van die Noordryk. Hy het ook sonder ophou beklemtoon hoe belangrik historiese kennis en begrip van die konteks is om die boodskap van ' $n$ boek te verstaan. In sy lesings en skryfwerk was W Vosloo altyd bedag daarop om die student, luisteraar en leser bekend te stel met die boodskap van die verskillende Bybelse boeke (vgl Vosloo 1989:xiii-xv; Vosloo s j:18-19; Uitgewer en redakteurs 1995:3-4; Uitgewer en redakteurs 1997:1-4; Vosloo \& Van Rensburg 1999:vii). Hy was eweneens daarop gesteld om die boodskap in die praktyk te laat grondvat (vgl Vosloo \& Van Rensburg 1993:xiv). Ek dra hierdie artikel baie graag op aan prof Wil Vosloo, wat vir my ' $n$ vriend, leermeester en, heel besonders, my Doktorvater, is.

Die historiese omstandighede wat tydens die bestaan van die Noordryk geheers het, sal baie kortliks bespreek word. Daarna sal ek die Ou-testamentiese literatuur wat hulle oorsprong in die Noordryk gehad het, aan die orde stel. Ek sal telkens fokus op die omstandighede waarin die materiaal tot stand gekom het en kortliks poog om die boodskap van die betrokke stuk literatuur te formuleer.

\section{HISTORIESE AGTERGROND VAN DIE NOORDRYK (ISRAEL)}

Die eenheidsryk van Israel, onder die koningskap van Dawid en Salomo, was ' $n$ relatief kortstondige politieke fenomeen. Uiteenlopende opvat tings bestaan oor hoe die twee konings en hulle koninkryk geëvalueer behoort te word. Sommige historici minimaliseer die rol van die twee figure Dawid en Salomo, en beskou die uitbeelding van hulle koninkryk as terugskouende idealisering. Die twee dele van Dawid en Salomo se 
koninkryk, die noorde en die suide, is verenig danksy die persoonlike betrokkenheid van die twee konings. Dawid was aanvanklik net koning van die suidelike stamme (2 Sam 2:1-11) en hy het by wyse van ' $n$ ooreenkoms ook koning in die noorde geword (2 Sam 5:1-5). Teen die einde van Dawid se lewe was daar ' $n$ hewige opvolgingstryd (vgl 2 Sam 9 - 1 Kon 2). Die aanspraakmakers op die troon was albei seuns van Dawid: Adonia en Salomo. Nadat Salomo die oorhand gekry en in Jerusalem koning geword het, is hy oënskynlik sonder meer ook in die noorde as koning aanvaar. Let egter daarop dat hy twaalf streekbestuurders in die hele Israel aangestel (het) met die oog op die onderhoud van die koning en sy hof (1 Kon 4:7). Nie een van hulle het gesorg dat Juda, Salomo se eie stam (gebied), ook ' $n$ twaalfde van die verantwoordelikheid neem vir die koning en sy hof nie (1 Kon 4:8-19). Dit is moontlik een van die redes waarom Salomo se seun, Rehabeam, nie ewe hartlik as koning in Sigem aanvaar is nie (1 Kon 12:1-4).

Daar is aanduidings dat die mense van die noorde en die suide nooit werklik verenig het nie. Hulle was bloot lotsverbonde onderdane van die heersende konings, Dawid en Salomo. Regdeur die bestaan van die verenigde koninkryk het verskillende opvattings oor God, die samelewing en koningskap in die twee dele van die koninkryk voortgeleef. Die verskille het ná die dood van Salomo weer skerp na vore getree.

Rehabeam, Salomo se seun en opvolger in Jerusalem, is nie outomaties deur die mense van die noordelike stamme as koning aanvaar nie. Rehabeam sou ook in Sigem, in die Noordryk, as koning aanvaar moes word. Die mense van die noorde was nie in alle opsigte tevrede met die wyse waarop hulle vanuit Jerusalem regeer is nie. Daarby het hulle ' $n$ sterk leier in die persoon van Jerobeam ben Nebat gehad (1 Kon 11:28).

Verskeie faktore het tot die broosheid van die verenigde ryk bygedra. Die bevolking van die noorde was anders saamgestel as dié van die suide. Die Israelitiese komponent van die bevolking van die Noordryk is aangevul deur ' $n$ sterk Kanaänitiese element. Dié twee groepe was naby aan mekaar verwant. Die belangrikste punt van onderskeid tussen die twee groepe was hulle godsdiens. Die Israeliete het Jahwe vereer en hulle geloof met die mense van Juda gedeel. Die Kanaäniete het verskeie ander gode soos El, Baäl Hadad, Resjef en Asjera vereer. Die onderskeid was egter nie altyd ewe helder nie, soos blyk uit Hosea se polemiek teen sy Jahwistiese geloofsgenote. Dat die godsdienstige prentjie in Juda egter nie veel minder gekompliseerd was nie, blyk duidelik Jeremia se godsdienskritiek (bv Jer 2:1-13) en later uit die vernietigende kritiek van Esegiël (bv Eseg 8:1-18).

Die Kanaäniete word tradisioneel met ' $n$ stedelike lewenswyse verbind. Hulle was dikwels welaf handelaars en dit was Kanaäniete wat ontwikkel het tot die seevarende handelaars van die Fenisiese stadstate soos Sidon en Tirus. Die Kanaäniete se taal, skryfwyse en godsdiens het 
' $n$ baie groot invloed op die Israeliete uitgeoefen. Die Israeliete was dikwels kleinboere en het in klein dorpies in die sentrale heuwelland van Palestina gewoon.

Die mense van die noorde het gevoel dat hulle in terme van belasting in die vorm van produkte, geld en diensplig te swaar deur Salomo belas is. Hulle sou Rehabeam net as koning aanvaar as hy sou onderneem om die las te verlig. Toe hy die versoek weier, was die skeuring van Dawid en Salomo se koninkryk ' $n$ voldonge feit. Hulle het hulle dislojaliteit aan die Dawidsdinastie ondubbelsinnig verklaar:

Toe die Israeliete hoor dat die koning nie aan hulle versoek voldoen het nie, het hulle vir hom gesê:

"Dawid is nie deel van ons nie; ons het niks aan Isaï se seun nie.

Elkeen terug na sy woonplek toe, Israel!

Kyk maar na jou eie huis, Dawid!"

Israel is toe terug na sy eie woongebied toe (1 Kon 12:16).

Vir die mense van die Noordryk was dit bloot ' $n$ terugkeer na hulle vroeëre onafhanklike bestaan. Hulle het Rehabeam verwerp en vir Jerobeam tot koning verkies. Jerobeam het aanvanklik vanuit Sigem regeer.

Dit was kenmerkend dat konings in die Noordryk veel makliker omvergewerp en deur ' $n$ ander vervang is. Die Dawidsdinastie het ' $n$ groot mate van stabiliteit in die koningskap van die Suidryk teweeggebring (twintig konings het in die ongeveer driehonderd en ses en dertig jaar tussen $922 \mathrm{vC}$ en $586 \mathrm{vC}$ wat die Suidryk bestaan het, regeer en daar was slegs drie staatsgrepe). In die Noordryk was dit anders: dinastiese opvolging, waar die seun sy vader as koning opvolg, was nie so vanselfsprekend nie. Die ideaal in die Noordryk was charismatiese leierskap, soos in die tyd van die Rigters. Die praktyk was egter gereelde gewelddadige staatsgrepe waarin konings mekaar ontsetel en opgevolg het. Die Noordryk het in net meer as tweehonderd jaar (vanaf 922 tot $722 / 1 \mathrm{vC}$ ) negentien konings gehad (of twintig as ' $\mathrm{n}$ mens vir Tibni bytel; vgl 1 Kon 16:21-22). Die presiese bepaling van die regeringstydperke van die konings van Israel en Juda is onmoontlik. Enige datering moet rekening hou met verskillende beginsels wat gegeld het vir die berekening van " $n$ koning se regeringstyd en die manier waarop jare en maande bereken is, asook met die probleem van gelyktydige regering (Galil 1996).

' $n$ Uitsondering op die reël van beperkte dinastiese opvolging was die dinastie van Omri. Die konings uit die Omri-huis het 'n belangrike rol in die geskiedenis van die Noordryk gespeel. Die dinastie het uit Omri, Agab, sy seun en Agab se twee seuns Ahasia en Joram bestaan. Hulle het Israel tusen $884 \mathrm{vC}$ en $842 / 1 \mathrm{vC}$ regeer. Omri was in terme van politieke en militêre prestasie een van die mees suksesvolle konings van Israel. Hy het het iets van die geïdealiseerde grootheid van die ryk van 
Dawid herstel. Hy het die Noordryk se grondgebied na die noordooste en die ooste vergroot en van die omringende volke aan hom onderhorig gemaak. Tog het die skrywer van 1 Konings nie veel aandag aan hom geskenk nie (1 Kon 16:23-28). Die rede hiervoor is teologies: Omri het, soos die ander konings van die Noordryk, nie die prioriteit van Jerusalem as enigste kultussentrum vir die verering van Jahwe erken nie. Daarom word geen enkele koning van die Noordryk in 1 en 2 Konings positief beoordeel vir sy suksesse as koning nie.

Ofskoon Omri se regeringstyd baie kort in die Koningsboek behandel word, is hy uit buite-Bybelse bronne aan ons bekend. Dit maak van hom een van die weinige Israelitiese konings wat uit buite-Bybelse geskrifte bekend is. Hierin verskil hy byvoorbeeld van Salomo wat uit geen ander bron as die Bybel aan ons bekend is nie. Uit die gegewens van die Mesa-inskripsie, wat uit ongeveer $835 \mathrm{vC}$ dateer, blyk dit dat Omri ' $n$ belangrike rol in die streekspolitiek van sy tyd gespeel het (Smelik 2000:137-138). Koning Mesa van Moab was in werklikheid 'n tydgenoot van Jehu. Jehu het nie alleen lank na Omri regeer nie, maar hy was ook verantwoordelik vir die uitwissing van die hele familie van Omri, optrede wat hewig deur die profeet Hosea gekritiseer is (vgl 2 Kon 8:24-9:14; Hos 1:4-5). Ten spyte van hierdie gebeure ken Mesa die koningshuis van Israel steeds as die huis van Omri.

Die teks van die Mesa-stela, wat oor Omri en Israel handel, is onlangs hervertaal en gepubliseer. Dit lui soos volg (Smelik 2000:137):

"Omri was the king of Israel, and he oppressed Moab for many days, for Kemosh was angry with his land.

And his son succeeded him, and he said - he too -

"I will oppress Moab!"

In my days did he say [so], but I looked down on him and on his house, and Israel had gone to ruin, yes, it has gone to ruin for ever! And Omri had taken possession of the whole la[n]d of Medeba, and he lived there (in) his days and half the days of his son, forty years, but Kemosh [resto]red it in my days."

Omri was nie net beroemd weens sy buitelandse suksesse nie. Dit was ook hy wat Samaria as nuwe hoofstad vir die Noordryk gebou het (1 Kon 16:24). In die Bybel word egter veel meer aandag aan Omri se seun Agab geskenk. Dit gebeur nie vanweë sy verbeeldingryke bouprojekte en klaarblyklik suksesvolle tyd as koning van Israel nie (vgl Stern 1993:1829), maar dit hou verband met die optrede van die profeet Elia, wat 'n 
tydgenoot van Agab was. Die regeringstyd van Agab was die historiese konteks van Elia se optrede (1 Kon 17:1).

Die Israeliete van die Noordryk was in sekere opsigte meer konserwatief as die mense van die Suidryk. Tradisionele stammewaardes, 'n oorblyfsel uit die tyd voor die koningskap, het in die Noordryk onder ' $\mathrm{n}$ gedeelte van die bevolking nog ' $n$ groot rol gespeel. Die nageslag van die mense wat die uittog uit Egipte meegemaak het en wat daardie herinneringe gekoester het, was hoofsaaklik in die Noordryk woonagtig (vgl Deist \& Le Roux 1987:68-97).

Dit was ook hoofsaaklik in die noordelike teologiese kringe waar die Wet van Moses sterk gefunksioneer het. Dit het neerslag gevind in die deuteronomiese teologie, wat sterk klem lê op tradisionele waardes. Dit was juis hierdie konserwatiewer teologie en samelewingswaardes wat gelei het tot die optrede van profete soos Elia en Elisa in die Noordryk (vgl 1 Kon 17 - 2 Kon 13). Hulle het opgetree en standpunt ingeneem teen spesifieke godsdienstige, sosiale en ekonomiese toestande in die Noordryk en het hulle ook teen sekere optredes van die koningshuis verset. Elia en Elisa het teen die middel van die negende eeu vC (ongeveer $840 \mathrm{vC}$ ) begin optree. Dit was ' $n$ volle eeu vroeër as wat die verskynsel van onafhanklike profeetskap, teenoor die hofprofete soos Natan, in die Suidryk sy verskyning gemaak het.

Uit die geskiedenis van die konflik tussen Elia en Agab blyk die verskille tussen die twee duidelik: Elia het ' $n$ puristiese godsdienstige verwagting van die koning. Hy meen die koning het ' $n$ plig om sekere tradisionele waardes te beskerm, terwyl Agab as koning gepoog het om die uiteenlopende behoeftes van ' $n$ heterogene bevolking in ' $n$ enkele koninkryk te bevredig (Deist \& Le Roux 1987:56-57).

Die Omri-dinastie het in Israel geheers in ' $n$ tyd toe die magtige Assiriese ryk in Mesopotamië besig was om tot stand te kom. Daar was 'n soort magsvakuum en die kleiner koninkryke soos Israel en Juda kon ' $n$ redelik selfstandige bestaan voer. Die ander volke wat in die tyd ' $n$ rol gespeel het was die Arameërs, wat ook in kleiner koninkryke georganiseerd was, die Fenisiërs, wat vanuit hulle stadstate langs die kus deur die hele Middellandse See-gebied handel gedryf het en wat deur die die huwelik tussen Agab en Isebel kontraktueel aan Israel verbonde was. Voorts was daar die volke oos van die Jordaanrivier: die Moabiete, Ammoniete en die Edomiete (Boshoff, Scheffler \& Spangenberg 2000:22-41).

Teen die tyd van koning Jehu, wat die nageslag van Agab uitgewis het, het die omstandighede verander. Jehu het die godsdienstig puristiese weg in sy regering gevolg, maar groot dele van die koninkryk van Israel aan die Arameërs afgestaan (2 Kon 10:32-33). Trouens, die tyd van Jehu was vir Israel ' $n$ tyd van verlies en agteruitgang. Die Arameërs het hulle mag algaande rondom Damaskus gekonsolideer en in koning Hasael het 
Israel ' $n$ aggressiewe buurman gehad wat hulle onder swaar druk geplaas het.

Jerobeam II van Israel het weer van die grondgebied terugverower. Hy het ' $n$ lang en voorspoedige tydperk as koning beleef tussen 790 en $750 \mathrm{vC}$. Die voorspoed het egter ook wantoestande meegebring en dit is die tyd waarin die skrifprofete Amos en Hosea na vore getree het. Hulle het kritiek op sosiale toestande en die styl van regering uitgeoefen.

Namate die internasionale politieke toneel verander het met die vestiging en groei van die Assiriese koninkryk, het Israel en die ander klein koninkryke toenemend onder druk verkeer. Die teenwoordigheid van die Assiriërs het weerstand by Israel en Damaskus gewek. Koning Peka van Israel en Resin van Damaskus het teen 734 vC probeer om Agas van Juda te dwing om saam met hulle teen Tiglat-Pileser in opstand te kom. Dit staan bekend as die Siro-Efraimitiese oorlog. Agas wou nie met die ander twee saamwerk nie en het die Assiriese koning Tiglat-Pileser se hulp teen Israel en Damaskus ingeroep. Tiglat-Pileser het dadelik ingegryp, Damaskus verower, Resin tereggestel en groot dele van Israel beset. Israel eers grondgebied aan die Assiriërs afgestaan en daarna is die hoofstad Samaria vir drie jaar lank beleër en in $722 \mathrm{vC}$ ingeneem (2 Kon 18:9-11). Dit het die einde van die Noordryk beteken (vgl Schoors 1998:94-95).

Die Ou-Testamentiese literatuur wat spesifiek aan die Noordryk verbind kan word, is meestal gefragmenteerd en in latere tye oorgewerk of in groter korpusse ingewerk. Tog is daar kenmerkende teologiese elemente wat dit moontlik maak om die literatuur te isoleer en te bestudeer. Die moontlikheid bestaan ook dat daar in ' $n$ boek soos Hosea, wat bekend is vir die moeilike Hebreeus waarin dit geskryf is, die neerslag van ' $n$ Noordrykse dialek gevind kan word.

\section{LITERATUUR UIT DIE NOORDRYK}

\subsection{Die Elohis (E)}

\subsubsection{Die omvang van die E-bron van die Pentateug}

Weens die diepgaande redaksionele werk wat tot die Pentateug gelei het, is die presiese omvang en inhoud van die E-bron, asook die ander bronne, onseker en omstrede (vgl Eissfeldt 1964:266-269; Fohrer 1968:152158; Soggin 1976:105-109; Rendtorff 1983:167; Kaiser1984:101-110; Gottwald 1985:348-351). In soverre as wat daar konsensus bestaan, kan die tekste wat $\mathrm{E}$ reflekteer versigtig soos volg aangedui word:

Genesis (Die Aartsvaderverhale)

$\begin{array}{ll}20: 1-18 & \text { Abraham, Sara en Abimelek } \\ 21: 1-21 & \text { Abraham, Sara en Hagar }\end{array}$


$21: 22-34$

22:1-19

24:1-67

27:1-45

28: $10-12,17-22$

29-34

35-37
Abraham se verbond met Abimeleg

Abraham moet vir Isak offer

Rebekka word Isak se vrou (met J)

Isak seën vir Jakob in plaas van Esau (met J)

Jakob se droom by Betel

Familiegeskiedenis van Jakob (met J-elemente)

Jakob, Esau, Josef (met J en P)

Eksodus (Die uittog uit Egipte en die openbaring by Sinai)
3:1-15
Elohim openbaar Hom aan Moses as Jahwe (met J)
11:1-3
Die tiende plaag aangekondig
$17: 1-7$
Moses kry water uit ' $n$ rots (met J)
18:1-27
Jetro besoek vir Moses (met J)
19:1-20
Die Sinai-episode (met J)
20:1-21
Die Dekaloog (met D en J)
20:22-23:19
Die Verbondsbepalings
32:1-35
Die goue kalf (met J)

Numeri (Die woestyntog na die Transjordaniese gebied)
12:1-16
Aäron en Miriam teen Moses (met J)
$13: 17-14: 25$
Verkenners na Kanaän gestuur (met $J$ )
21:4-9
22:2-24:25
Die bronsslang (met J)
$32: 1-38$
Balaam
Gad en Ruben oos van die Jordaan (met J)

Deuteronomium (Moses se laaste woorde en sy dood)

31:14-23

$32: 1-43$

33:1-29

$34: 1-12$
Aanwysing van Josua (met J)

'n Gedig oor die Uittog

Moses seën die stamme

Moses sterf (met J)

\subsection{2 'n Konteks vir E}

Die Elohis is ' $n$ fragmentariese weergawe van Israel se hele vroeë geskiedenis. Die inhoud loop parallel aan die ander vroeë dokument van die Pentateug, naamlik die Jahwis. Die Jahwis het waarskynlik tussen 960 en 930 vC in die dampkring van die koninklike hof in Jerusalem, ontstaan. Die Elohis het sy oorsprong waarskynlik in die Noordryk ná die skeuring van die ryk, maar voor die val van die Noordryk tussen 922 en 722 vC (Jenks 1977). Albei die bronne vertel die geskiedenis van die aartsvaders af tot pas voor die inbesitname van die land Kanaän. As ' $n$ mens die verband tussen $E$ en die profetiese tradisie in ag neem, asook die vredevolle bestaan van die mense onder die monargie (vgl Num 23:21; Deut 33:13-17), is dit moontlik om $\mathrm{E}$ in die tyd van koning Jerobeam II van Israel te dateer. Dit is voor $750 \mathrm{vC}$ (Fohrer 1968:158). 
Kenmerkend van $\mathrm{E}$ is die naam Elohim wat aanvanklik vir Israel se God gebruik word. Dit sluit aan by die opvatting dat Jahwe se naam deur Moses aan Israel bekend gemaak is (Eks 3:1-15). Dit is egter nie die enigste kenmerk van $\mathrm{E}$ nie. Alhoewel $\mathrm{E}$ in talle opsigte met $\mathrm{J}$ ooreenstem, is daar duidelike verskille in woordeskat en skryfstyl en klem. Enersyds behandel $\mathrm{E}$ al die belangrikste historiese temas wat in $\mathrm{J}$ voorkom. Andersyds is daar ' $n$ aantal vertellings of tradisie-eenhede in $E$ wat nie by J voorkom nie (Gottwald 1985:138). Die skrywer(s) van E het besondere waarde geheg aan die verbondsverbintenis tussen Israel en Jahwe. Hulle het dié verbintenis beskou as ouer en meer grondliggend aan die bestaan van Israel as die Dawidsdinastie in Jerusalem, of die jongere koninkryk van Israel.

As ' $\mathrm{n}$ mens $\mathrm{J}$ beskou as die produk van mense ná aan die koninklike hof in Jerusalem, sou die profetiese sirkels van die Noordryk, wat die Elia- en Elisa-tradisies lewend gehou het, die plek wees om E se skrywers te soek. E definieer Israel só dat dit bo die bestaande koninkryke van Juda en Israel uitstyg en huiwer nie om die status quo te kritiseer nie. In daardie sin was $E$ moontlik bedoel as ' $n$ korrektief op $J$ wat meer versigtig was om die politieke maghebbers te kritiseer (Gottwald 1985:138).

\subsubsection{Die boodskap van die Elohis}

Die Elohis beklemtoon die beeld van vroeë Israel as ' $n$ gemeenskap wat godsdienstig en eties in ' $\mathrm{n}$ verbondsverhouding met Jahwe gestaan het. Dit lei tot ' $n$ beskouing oor die uniekheid van Jahwe teenoor die gode van Kanaän. Hierin sluit E nou aan by die profete van die Noordryk soos Elia en Hosea (vgl Eissfeldt 1964:267; Gottwald 1985:138). J skenk besondere aandag aan historiese en politieke gebeure, terwyl E dit nie doen nie. In $\mathrm{J}$ is daar ' $\mathrm{n}$ direkte verbinding tussen die aartsvaders en Jahwe. E beskryf kontak tussen God en mens as iets wat bemiddel word: dit gebeur deur engele of drome waarin God sy wil bekend maak en daar word heel dikwels gewag gemaak van wonderwerke waardeur die mag van die God van Israel beklemtoon word. E plaas besondere klem op teologiese en etiese probleme, terwyl hy baie skerp reageer teen die Kanaänitiese godsdiens en gebruike. Dit stem ooreen met die godsdienstige konflik van die profete van die Noordryk met die Baälgodsdiens van die Kanaäniete (vgl Fohrer 1968:157). In teenstelling hiermee het J, soos Dawid en Salomo, oënskynlik min probleme met die Kanaäniete gehad. Waar J die teologiese legitimasie vir die verenigde ryk van Dawid en Salomo moes voorsien, het $\mathrm{E}$ die basis gevorm vir die regverdiging van die bestaan van die Noordryk. 


\subsection{Die Elia- en Elisatradisies}

\subsubsection{Die Elia- en Elisatradisies in 1 en 2 Konings}

Die Elia- en Elisatradisies is tussen 1 Konings 17 en 2 Konings 13 in die koningsgeskiedenis ingeweef.

Die Elia-siklus behels: 1 Konings

17:1-19:19a Die groot droogte, die Karmelbergkonflik en Elia vlug suid

(19:19b-21 Elia wys Elisa aan as sy opvolger)

21:1-29 Nabot se wingerd

2 Konings

1:2-17a Elia en Ahasia

Die Elisa-siklus behels: 1 Konings

19:19b-21 Elia wys Elisa aan as sy opvolger

2 Konings

2:1-24 Elia word weggeneem. Elisa volg Elia op

4:1-44 Wonderwerkverhale

5:1-27 Elisa en Naäman

6:1-23 Wonderwerkverhale

6:31-7:20 Die Arameërs vlug

8:1-6 'n Koning laat reg geskied aan 'n weduwee

8:7-15 Gasael word koning oor Aram

9:1-3 Elisa laat vir Jehu salf

13:14-22 Elisa sterf

\subsection{2 'n Konteks vir die Elia- en Elisatradisies}

Die tradisies rondom die profete Elia en Elisa het hulle oorsprong in die Noordryk gehad. Hulle het in die Noordryk opgetree, daar hulle boodskap gebring en wonderwerke gedoen. Die oordraers van die verhale was waarskynlik deel van armer groeperinge op die buiterand van die Israelitiese samelewing, wat deur probleme soos hongersnood en minagting deur die regstelsel geteister is. Hulle was moontlik lede van die profetegroepe waarvan daar veral in die Elisaverhale sprake is. Hulle het kennelik nie van die staat hulp verwag nie en was skepties oor die konings se toewyding om Jahwe in staatsverband te vereer. Hulle opvatting oor hoe Jahwe vereer behoort te word, was eksklusief, tot uitsluiting van enige eksterne invloede uit die Kanaänitiese wêreld. Dit is egter ironies om daarop te let dat selfs toe een van hulle "eie mense", Jehu, die troon bestyg het, dit vir hom nie moontlik was om om die suiwere diens aan Jahwe in ' $n$ staatstelsel vir Israel te omvorm nie (vgl Gottwald 1985:342). 
Volgens 1 Konings 17:1 was Elia, die Tisbiet, “" $n$ bywoner uit Gilead". Dit beteken dat hy uit die Transjordaniese gebied wat in daardie tyd deel van die Noordryk was, afkomstig was. Elisa was ook ' $n$ boorling van die Noordryk, uit Abel-Megola in die Jordaanvallei, suid van Bet-San. Die twee profete se optrede en invloedsfeer was egter nie tot Israel beperk nie. Elia reis na die Transjordaan (om by die spruit Krit te gaan skuil - 1 Kon 17:2-7), na Fenisië (om in Sarfat by Sidon te gaan bly - 1 Kon 17:8-24), na Juda en die Negev tot by Horeb, die berg van God (om van alles af weg te kom - 1 Kon 19:3-18). Elisa is onder meer Aram toe om vir Gasael daar as koning te gaan salf (2 Kon 7-15).

Die historiese akkuraatheid van die verhale is nie maklik om vas te stel nie. Die verhale dra ' $n$ legendariese karakter wat versterk word deur die anonieme profeteverhale wat tussen die ander in vertel word (vgl 1 Kon 20:13-14, 22, 28,35-42). Wat egter nie betwyfel kan word nie is die feit dat die verhale binne die konteks van die Omri- en Jehu-dinastieë van Israel en hulle Aramese tydgenote in die negende eeu $\mathrm{vC}$ vertel word. Elia het teen $870 \mathrm{vC}$ begin optree en Elisa het teen $848 \mathrm{vC}$ by hom oorgeneem.

Die godsdiens-historiese en kulturele omstandighede wat in die verhale uitgebeeld word, stem ooreen met die argeologiese gegewens wat lig werp op hierdie tydperk (Stern 1993:18-29). Die Noordryk het noue bande met die Fenisiërs gehandhaaf, soos wat gesuggereer word deur Agab se huwelik met die Fenisiese prinses Isebel. Dit word ryklik bevestig deur die resultate van opgrawings in Samaria (Avigad 1993:1302-1306) en Tel Dor (Stern 2000:85-148, 353-363). Die godsdienstige praktyke het ruimte gelaat vir die verering van die Kanaänitiese gode en godinne soos Baäl en Asjera, sowel as die Jahwe-kultus wat daarteenoor gestaan het. Sommige mense in die Noordryk het ' $n$ suiwer Kanaänitiese godsdiens beoefen, terwyl ander, van wie Elia 'n voorbeeld is, die uitsluitlike verering van Jahwe nagestreef het. Daarbenewens was daar waarskynlik mense wat nie skerp onderskei het nie en wat ' $n$ gemengde godsdiens beoefen het sonder om te veel daaroor na te dink.

\subsubsection{Die boodskap van die Elia- en Elisatradisies}

Konflik, gebaseer op godsdienstige verskille, is die basis van die Eliaverhale. Die persone teenoor wie Elia homself stel, wissel, maar of dit nou koning Agab, sy vrou Isebel, die Baäl- en Asjera priesters of koning Ahasia is met wie hy bots, die rede vir die botsing is telkens botsende godsdienstige opvattings. Elia het besondere klem op die uniekheid van Jahwe, die God van Israel, gelê. Daar was vir hom geen ruimte waar Jahwe en die gode van die Kanaäniete saam kon bestaan nie. Kernagtig kan sy boodskap saamgevat word in sy vraag aan die Israeliete in 1 Konings 18:21: 
"Hoe lank hou julle aan met hink op twee gedagtes? As die Here God is, volg Hòm; maar as dit Baäl is, volg hòm."

Daar was vir Elia ook net een God werksaam in Israel en dit is Jahwe. Dit word treffend geillustreer in sy botsing met Ahasia in 2 Konings 1:3,6 en 16 waar hy van Ahasia wil weet:

"Is daar dan geen god in Israel nie dat jy boodskappers stuur om Baäl-Sebub die god van Ekron te raadpleeg?"

Elisa word veral as wonderwerker uitgebeeld. Sommige van sy wonderwerke herinner aan die wonderwerke wat Elia gedoen het (vgl 2 Kon 4:1-7 en 8-37 met 1 Kon 17:8-16 en 17-24). Elisa het egter ook ' $n$ rol op die politieke toneel gespeel, nie alleen in Israel nie, maar ook in Aram, Israel se noordelike buurstaat, waar hy vir Gasael as koning gaan aanwys het (2 Kon 8:7-15). Hierdeur word Jahwe voorgestel as God wat benewens die Israeliete se praktiese godsdiensbeoefening en die natuur òòk by politiek en staatssake betrokke is. Dit word ook duidelik dat Jahwe nie slegs by Israel betrokke is nie, maar ook veel wyer.

\subsection{Die boek Amos}

\subsection{1 'n Konteks vir die profeet Amos en die boek Amos}

Volgens die opskrif tot die boek was die profeet Amos ' $n$ man uit Tekoa in die Suidryk. Hy het egter sy boodskap in Samaria en Betel, in die Noordryk, gaan oordra. Dit het gedurende die agste eeu vC gebeur, so ongeveer tussen $762 \mathrm{vC}$ en $750 \mathrm{vC}$, in die tyd toe koning Jerobeam II in Samaria en koning Ussia in Jerusalem regeer het (Am 1:1). Jerobeam II se regeringstyd (wat oor veertig jaar tussen $786 \mathrm{vC}$ en $746 \mathrm{vC}$ gestrek het), is op internasionale gebied gekenmerk deur vrede en stabiliteit, terwyl ekonomiese voorspoed en welvaart in die Noordryk geheers het. Dié stabiliteit was die direkte gevolg van die agteruitgang van die Aramese staat, Damaskus, onder die druk wat die opkomende Assiriese koninkryk op die streek uitgeoefen het (Donner 1977:414).

Amos self was bes moontlik ekonomies onafhanklik en ons verneem dat hy ' $n$ veeboer (Am 1:1) en ' $n$ kweker van wildevye was (Am 7:14). ' $n$ Veeboer moet duidelik onderskei word van 'n skaapherder, wat eintlik ' $n$ onbeduidende persoon was. Wildevye is aan die Dooie See en langs die Middellandse See verbou en nie in die omgewing van Tekoa in Juda nie. Dit alles beteken dat Amos moontlik ' $n$ wydberese man was wat veel wyer as die grense van Tekoa alleen beweeg het. In die proses het hy onder meer kennis gemaak met die tradisionele wysheid van Israel (Wolff 1969:108; vgl ook Deist 1991). 
'n Tyd van welvaart, soos dié waarin Amos en Jerobeam II geleef het, is dikwels ook ' $n$ tyd van sosiale onreg. Daarvan lewer die boek Amos oorvloedige getuienis. Die rykes van Samaria was baie ryk, terwyl die armes nie alleen min besit het nie, maar hulle is ook nog deur die regspraak benadeel. Dit is teen sulke misstande wat Amos gepreek het.

Die profeet self was verantwoordelik vir verskeie dele van die boek, terwyl mense uit ' $n$ groep Amos-ondersteuners selfs ná sy dood van sy vertellinge wakker gehou het. $\mathrm{Na}$ die val van Samaria in $721 \mathrm{vC}$ is die versameling Amos-uitsprake deur vlugtelinge na Jerusalem toe geneem waar dit verder uitgebrei is en die boodskap ook op Jerusalem toegepas is. Ná die Judese ballingskap het die boodskap van Amos steeds gewig gedra en die boek is deur " $n$ deuteronomistiese hand hersien en van 'n opskrif voorsien (vgl Schoors 1998:137-8).

Die boek Amos het 'n redelike deurlopende tema van waarskuwing en oordeel. Dit kan soos volg ingedeel word: Amos 1-2 (Oordeelsaankondiginge oor agt nasies); Amos 3-6 (Oordeelspreke teen Israel); Amos 7-9:10 (Oordeelsvisioene teen Israel) en Amos 9:11-15 ('n Hoopvolle slot).

\subsubsection{Die boodskap van Amos}

Die boek Amos begin met agt vernietigende oordeelsaankondigings. Dit begin by die volkere rondom Israel, maar bou op na ' $n$ hoogtepunt waarin eers Juda (Am 2:4-5) en uiteindelik Israel self in die beskuldigdebank staan (Am 2:6-16). Die beskuldiging teen Israel bevat die meeste besonderhede en handel oor die onreg wat daar in die samelewing teen arm, swak en weerlose mense gepleeg is en oor die toestand waarin die kultus, dit is die Israeliete se godsdiensbeoefening, was.

Amos verkondig straf aan die mense van Israel. Hy verset hom ten die onreg en uitbuiting van armes en swakkes deur die rykes en leiers van Samaria wat in groot weelde en selfvoldaanheid leef (vgl Am 3:10; $4: 1 ; 5: 7 ; 5: 10-11 ; 6: 1)$. Daarby ruim Amos twee groot misverstande uit die weg: die Israeliete het die Dag van die Here verwag as 'n dag waarop Jahwe die oorwinning ten behoewe van Israel sou behaal, nou verkondig Amos die Dag van die Here as 'n oordeelsdag wat geen vreugde sal inhou nie (Am 2:18-20). Die ander misverstand hou verband met Israel se uitverkiesing deur God. Enersyds bevestig Amos Israel se besondere posisie voor God, maar dit word 'n deel van die rede vir God se oordeel:

Ek het net vir julle uitgekies

uit al die volke van die aarde

daarom sal Ek julle straf

oor al julle sondes (Am 3:2).

Andersyds beklemtoon Amos dit dat God ook wyer gewerk het as net met Israel. In Amos 9:7 stel hy Israel eintlik gelyk aan die ander volkere: 
Julle Israeliete is vir my nie anders as die Kussiete nie, sê die Here.

Ek het vir Israel uit Egipte laat trek, maar ook die Filistyne uit Kaftor

en die Arameërs uit Kir.

Met die uitspraak dui Amos aan dat Israel se uitverkiesing nie ' $n$ blote bevoorregting deur God is nie. As dit nie gepaard gaan met ' $n$ lewe volgens die verwagtinge wat God stel nie, sal Hy dit verwerp en straf:

Al die sondaars onder my volk

sal met die swaard doodgemaak word,

hulle wat sê:

"Ter wille van ons sal u die ramp nie laat kom nie,

ons nie daardeur laat tref nie" (Am 9:10).

' $n$ Soortgelyke verwagting in Juda, dat God sy volk onvoorwaardelik sal beskerm, is veel later deur die profeet Jeremia weerspreek (vgl Jer 7:311).

Amos verkondig egter ook heil, in " $n$ tyd wanneer Jahwe die lot van sy volk sal verander en wanneer dit goed sal gaan (Am 9:11-15).

\subsection{Die boek Hosea}

\subsection{1 'n Konteks vir die profeet Hosea en die boek Hosea}

Die profeet Hosea was ' $n$ jonger tydgenoot van Amos. Hy het ook in die Noordryk opgetree, volgens die deuteronomistiese inleiding aanvanklik in die tyd van koning Jerobeam II. Van sy persoonlike geskiedenis weet ons min. Die inleiding (Hos 1:1) dui aan dat hy die seun van Beëri was. Van Beëri weet ons niks nie. Hoofstukke 1 en 3 handel oor sy huwelik en gesinslewe, maar die vertellings gaan byna naatloos oor in prediking oor die verhouding tussen Jahwe en Israel. Sy huwelik(e) vorm ' $n$ wesenlike deel van die boodskap. Die huwelik met Gomer was simbolies van Israel se ontroue verhouding met Jahwe (vgl Boshoff 1994:329339). Die drie kinders wat uit die huwelik gebore het elkeen ' $n$ simboliese naam gekry wat die boodskap van Hosea moes illustreer. Die oudste seun is Jisreël genoem. Die naam verwys na die stad Jisreël waar Jehu in ' $n$ staatsgreep vir Joram, die koning van Israel en vir koning Ahasia van Juda vermoor het. Hy het toe self koning van Israel geword (vgl 2 Kon 9). Daarna het hy in ' $n$ bloedbad al die nakomelinge van Agab, sowel as die amptenare en die vertrouelinge van die vorige dinastie uitgewis (2 Kon 10:1-11). Die tweede kind was ' $n$ dogter met die naam Lo Rugama (Sonder-ontferming) en die derde weer ' $n$ seun, Lo Ammi (Nie-my-volk-nie). Die twee name simboliseer die groeiende verwydering tussen Jahwe en Israel.

Hosea se kritiek was hoofsaaklik op drie aspekte van Israel se lewe gerig: 
hulle militêre selfvertroue en chaotiese interne politiek (vgl Hos 7:3-7),

* hulle buitelandse politiek en die sluit van verdrae (vgl Hos 8:8$10)$.

Hosea was ' $n$ getuie van die voorspoedige tyd tydens die regering van Jerobeam II, die vinnige verwisseling van konings na hom, die SiroEfraimitiese oorlog (toe Israel met die Arameërs saamgespan het om teen Juda te veg, (vlg Hos 5:8-6:6 en 2 Kon 16:1-8) en die spanningsvolle tyd met die opkoms van die Assiriese ryk, voor die val van Samaria (Macintosh 1997:xciv). Dit is nie duidelik of hy die val van Samaria ook beleef het nie, maar dit is onwaarskynlik, omdat hy nie direk na die gebeure verwys nie (Gottwald 1987:362 sien dit anders).

Hosea was waarskynlik ' $n$ boorling van die Noordryk. Hy was baie goed onderlê in die historiese tradisies van Israel en op hoogte van die politieke bedrywighede. Hy verstaan ook die hart van Israel se godsdiens en skenk aandag aan die godsdiensbeoefening by Betel, Samaria en ander belangrike plekke (Wolff 1965:xix). Die Hebreeus waarin die boek geskryf is, is besonder moeilik en die gedagte bestaan dat dit ' $n$ oorblyfsel van ' $n$ Noordrykse dialek of taalvariant kan wees.

Die boek Hosea het oor ' $n$ tydperk heen tot stand gekom. Die profeet self het moontlik ' $n$ deel daarvan self geskryf (Hosea 3), maar verder is van sy uitsprake deur aanhangers versamel en neergeskryf. Ná die val van Samaria is die boek deur Israelitiese vlugtelinge, moontlik Leviete, na Juda gebring. In Jerusalem is sy waarskuwings gelees teen die agtergrond van die val van Samaria. Erkenning is verleen aan die manier waarop sy waarskuwings waar geword het en dit is vir die Judese situasie herinterpreteer. $\mathrm{Na}$ die ballingskap is die boek van ' $\mathrm{n}$ inleiding en slot voorsien (Hos 1:1 en 14:10) en volgens sommige geleerdes omvattend herskryf (Yee 1987:120-122, 131-259). Unieke kenmerke van die boek Hosea wat op die agtste eeuse profeet teruggaan, is die polemiek teen die Baälgodsdiens en die herinterpreterasie van Jahwe se betrokkenheid by Israel en hulle leefwêreld. Hosea het die reikwydte van Jahwe se aktiwiteitsveld só herdefinieer dat die natuur en vrugbaarheid voortaan as die werk van Jahwe gesien is en nie meer aan ander gode in die Kanaänitiese panteon, soos Baäl, toegeskryf sou word nie (Boshoff 1992:13-24; 1997:1-21).

Vosloo (1992:244-252) verdeel die inhoud van die boek soos volg: Hosea 1:1 (Die inleiding); 1:2-3:5 (Die ontrou van Israel); 4:1-9:9 (Die "kennis" van Jahwe ontbreek); 9:10-11:11 (Die verlore onskuld van Israel se jeug); 12:1-14:1 (Die hede in die lig van die verlede); 14:2-9 (Jahwe, die getroue); 14:10 (Slot). 


\subsubsection{Boodskap}

Hosea se sentrale boodskap is teen die godsdiens van Israel gerig (Boshoff, in druk). Terwyl hulle dink dat hulle Jahwe, die God van Israel vereer, is hulle volgens Hosea eintlik besig om die Kanaänitiese Baäls te vereer. In Hosea staan die begrip "Baäls" vir die gode en godinne van die Kanaäniete se natuurgodsdiens. Die godsdiens was daarop ingestel om die vrugbaarheid van die land, die veestapel en die mense te verseker. Hosea verklaar dat Jahwe volle beheer het oor die ganse werklikheid. Hy is nie alleen die God van Israel se geskiedenis nie (daaroor glo Hosea dat hy en die Israeliete tot wie hy hom rig saamstem). Jahwe is vir hulle almal die nasionale God van Israel (Boshoff 1994a:219-225). Maar Hosea verkondig dat Jahwe ook die God van die natuur en alle aspekte van die natuur is: die weer, lewenskrag, vrugbaarheid en die siklus van seisoene is alles binne sy invloedsfeer (Boshoff 1994a: 225-231).

Hosea stel Israel se vroeë geskiedenis in die woestyn voor as die ideale periode in die verhouding tussen Israel en Jahwe (Hos 13:4-5). Daarna het daar egter vervreemding en "ontrou" in die verhouding ingetree - dít is wat deur Hosea se huwelik uitgebeeld moes word (Hos 13:6). Hosea rig ook hewige kritiek teen die leiers van Israel. Sowel die priesters as die koning en ander politieke hoëlui word daarvan beskuldig dat hulle ontrou was aan die eise wat die Here aan hulle ampte gestel het (vgl Hos 4:1-5:8).

Hosea verkondig ook hoop op herstel, maar eers nadat Israel hulle foute ingesien het en hulle daarvan bekeer het. In Hosea 11 verkondig Jahwe sy liefde en lojaliteit en dit word in hoofstuk 14 opgevolg met ' $n$ belofte van totale herstel van die verhouding tussen God en sy mense, as hulle hulle tot God bekeer.

\subsection{Deutero-Miga}

\subsubsection{Die moontlike bestaan van 'n Noordrykse profeet, genoem Deutero-Miga}

Die boek Miga bevat twee hoofstukke (Miga 6-7) wat bes moontlik die werk van 'n Noordrykse profeet kon gewees het (Burkitt 1926:159-161; Van der Woude 1977:195-199; Strydom 1988). Fohrer (1968:446) sien dit anders en beskou die hoofstukke as later byvoegings tot die boodskap van Miga.

Die twee hoofstukke word soms Deutero-Miga genoem. Van der Woude (1977:195-196) voer die volgende redes aan vir die teorie dat dit wel van ' $n$ ander profeet uit die Noordryk afkomstig is:

* $\quad$ Ooreenstemming met ander profete: Miga 1-5 stem in baie opsigte ooreen met Jesaja, terwyl Miga 6-7 invloed van Hosea vertoon. 
Spesifieke aanduidings: Miga 6-7 gebruik geografiese aanduidings (bv Sittim, Gilgal, Karmel, Basan en Gilead) en eiename (Omri en Agab) wat op die Noordryk dui, sonder enige verwysings na die Suidryk. Miga 1-5 bevat slegs een verwysing na Samaria (Miga 1:6-9) (vgl ook Burkitt 1926:160).

* Teologiese tradisies: In Miga 1-5 figureer die Sionstradisie, wat Jerusalem beklemtoon, baie sterk (weliswaar krities), terwyl Miga 6-7 die Uittog- en Landinbesitnemingstradisies beklemtoon wat veral in die Noordryk belangrik was.

* Ontvangers van die profete se boodskap: In Miga 1-5 word die leiers en voorgangers veral aangespreek, terwyl die boodskap in Miga 6-7 meer tot die mense in die algemeen of tot ' $n$ stad in sy geheel gerig word.

* Inleidingsvers: Miga 1:1, die algemene inleiding tot die boek, sê dit "handel oor Samaria en Jerusalem". Dit beteken die Noordryk en die Suidryk.

Ons weet niks meer van die hipotetiese profeet nie, maar sy boodskap sluit nou aan by die kritiek op die godsdiens van Israel, wat tipies is van Hosea, en ook by die sosiale kritiek van Amos. Die taal en styl is tipies van die (proto-)deuteronomistiese kringe wat ons ook uit Hosea ken (Van der Woude 1977:197). Die tyd van sy optrede kan in die tyd voordat Samaria in $721 \mathrm{vC}$ deur die Assiriërs ingeneem is, geplaas word. Dit beteken dat die Noordrykse Miga voor die tyd van Miga van Moreset, die Suidrykse profeet, opgetree het. Miga van Moreset was ' $n$ tydgenoot van koning Hiskia van Juda wat tot in $697 \mathrm{vC}$ in Jerusalem koning was.

Die inhoud van Deutero-Miga, kan in navolging van Van der Woude (1977:200-268) soos volg ingedeel word: Miga 6:1-8 ('n Regsaak: Dít is wat die Here verwag); 6:9-16 (Oordeel oor die stad waar die reg ontbreek); 7:1-7 ('n Profetiese klag oor die gebrek aan lojaliteit); 7:8-20 (' $n$ Lied oor God se straf, vergifnis en trou).

\subsubsection{Die boodskap van Deutero-Miga}

In terme tipies aan die profete van die Noordryk, verkondig DeuteroMiga die uniekheid van Jahwe, Israel se God. Hy trek te velde teen die godsdiens van Israel as ' $\mathrm{n}$ teken van ontrou aan die God van Israel se geskiedenis:

Jy het Omri se reëlings nagekom, gedoen wat Agab gedoen het, hulle raad gevolg.

Daarom sal ek jou verwoes, Ek sal jou inwoners ' $n$ bespotting maak.

Jy sal my volk se vernedering moet dra (Miga 7:16). 
Hy preek teen misstande op godsdienstige en sosiaal-ekonomiese gebied in Israel en spreek die mense van Samaria aan:

Goddelose plek,

Moet Ek die verkeerde maatlyn bly verdra?

Of die vals inhoudsmaat wat Ek so haat?

Moet $E k$ die eienaar van ' $n$ onbetroubare weegskaal vryspreek,

een met ' $n$ sak vol vals gewigte?

Die stad se ryk mense pleeg geweld,

sy inwoners lieg en hulle bedrieg (Miga 6:10-12).

Tegelyk verkondig hy egter ook die reddende God wat sy beloftes van die verlede nie vergeet nie en wat eis dat mense aan mekaar reg moet doen:

Mens, die Here het jou bekend gemaak wat goed is:

Hy vra van jou dat jy reg sal laat geskied,

dat jy liefde en trou sal bewys,

dat jy bedagsaam sal lewe voor jou God (Miga 6:8).

Deutero-Miga sluit aan by die godsbeskouing en denke van die protodeuteronomistiese groepe, wat ook in Hosea en die oudste dele van Deuteronomium neerslag gevind het. Dit handel oor die uniekheid van Jahwe, teenoor die Kanaänitiese kultus, ' $n$ lewe volgens die tradisionele godsreg van Israel en trou aan die verbond, klem op die tradisionele erfenis wat elke stam in die beloofde land van Jahwe ontvang het en die verwysing na Jahwe se beloftes aan die aartsvaders (vgl Van der Woude 1977:199).

\subsection{Die basis van Deuteronomium}

Die groeibodem van die vroegste wortels van Deuteronomium was die Noordrykse levitiese en profetiese sirkels. Dit het moontlik in die welvaartsperiode tydens die regering van Jerobeam II gebeur. Die antieke heiligdom by Sigem of Betel was waarskynlik die sentrum waar sekere historiese tradisies van Israel sorgvuldig bewaar is (Von $\operatorname{Rad} 1966: 26$ ).

Die inhoud en boodskap van die tradisies het gehandel oor:

* Jahwe as God van Israel se geskiedenis, deur die uittog uit Egipte en die proses om die land Kanaän in besit te neem;

* die eis dat Jahwe alleen vereer behoort te word en dat daar geen gode buiten Jahwe bestaan nie. 
Ander plekke in die Bybel waar ' $\mathrm{n}$ mens tekens vind van die vroeë Deuteronomiese denke is by die Elia-vertellings (1 Kon 17-2 Kon 1) en by Hosea. Nadat Samaria in $721 \mathrm{vC}$ deur die Assiriërs ingeneem is, het van die vlugtelinge uit Samaria met die godsdienstige materiaal na Jerusalem toe gevlug. Daar is dit by die tradisies wat in Jerusalem in die tempel in omloop was, geïnkorporeer en in die proses hersien (Fohrer 1968:175). Die dokument wat so tot stand gekom het, was waarskynlik die basis vir die dokument (die "Wetboek") wat ongeveer 'n eeu later in die tyd van koning Josia in die tempel ontdek is (2 Kon 22:3-23:3). Die dokument het tot ' $\mathrm{n}$ godsdienstige hervorming in Juda gelei (vgl 2 Kon 23:4-27). Later is die dokument verwerk tot die Deuteronomiumboek (vgl Fohrer 1968:175-176; Soggin1976:122). Die wyse waarop daar in Deuteronomium oor God gedink is, het ook ' $n$ groot invloed op die profeet Jeremia uitgeoefen, terwyl ' $n$ volledige geskiedenis van Israel, die Deuteronomistiese Geskiedwerk ) ook vanuit hierdie perspektief geskryf is.

\subsection{Die annale van die konings van Israel}

"n Laaste brok literatuur uit die Noordryk is "die annale van die konings van Israel" wat die skrywers van 1 en 2 Konings as bron vir die geskiedenis van die konings van die Noordryk gebruik het. Die eerste verwysing na die annale is in 1 Konings 14:19 (i v m Jerobeam I) en daarna is daar sestien verwysings, tot by Peka, die voorlaaste koning van Israel ( 2 Kon 15:31). 'n Soortgelyke bron oor die konings van Juda het ook bestaan en is parallel deur die deuteronomistiese geskiedskrywer benut (Fohrer 1968:95-99; Soggin 1976:202).

Die annale is nie andersins bekend as deur die verwysings daarna in 1 en 2 Konings nie. Dit blyk dat die annale aan die koninklike hof gehou is en dat dit veral datums van regering en notas oor spesifieke gebeure bevat het. Nêrens word vermeld hoe die annale presies gehou is nie, maar dit kan waarskynlik met soortgelyke Babiloniese koningsannale wat in Babel opgegrawe is, vergelyk word. Geen tekens van die annale is in opgrawings by Samaria of Jerusalem gevind nie. Dit het waarskynlik in die beleg en vernietiging van die stede verlore gegaan.

Fohrer (1968:97-98) meen dat die afsonderlike annale van Israel en Juda deur die skrywers van Konings in hulle skryfwerk gekombineer is. Dit bied ' $n$ verklaring vir die talle probleme met datering tussen die konings van Israel en Juda. Elke koning word in terme van sy tydgenote in die ander koninkryk se regeringsdatums beskryf.

Benewens die annale was daar ook nog mondelinge vertellings van profete en ander persone wat met die geskiedenisse van die verskillende konings vervleg is om ' $n$ samehangende beeld te skep van die geskiedenis van die twee koninkryke van Israel en Juda. Daar is egter geen aanduiding van die bronne vir dié verhale nie. 
Die literatuur met hulle oorsprong in die Noordryk van Israel dra ' $n$ baie besondere boodskap oor. Verskeie van die vroegste profetefigure, soos Elia, Elisa, Amos en Hosea het in die Noordryk opgetree. Hulle bestaan het direk verband gehou met die bestaan van die koningskap in Israel. Die politieke en godsdienstige omstandighede het die ruimte geskep waarin hulle kritiese boodskappe groot betekenis gedra het.

Byna al die literatuur wat met die Noordryk verbind kan word, het ' $n$ sterk verband met die profete. Die profete het dikwels gewaarsku dat die verhouding tussen die Here en sy volk verkeerd geloop het en dat dit op ' $n$ krisis afstuur. In plaas daarvan dat die groot dag van die Here vir Israel voordeel en redding sou inhou, sou dit ' $n$ dag van oordeel en vernietiging wees. Dié waarskuwing is reeds deur Amos aan sy tydgenote gerig. Met die val van Samaria in $721 \mathrm{vC}$ is die profetiese waarskuwings as waar bewys. Dit het nie net in die Noordryk neerslag gevind nie, maar ook in Juda. In Jerusalem is sommige van die vertellings oor profete soos Elia en Elisa en die geskrifte van Amos en Hosea versamel en bestudeer en opnuut toegepas. Dié profete is beskou as mense wat die woord van die Here akkuraat oorgedra het.

Die geweldige krisis waarin die val van Samaria die mense van die Noordryk gedompel het, het in die Suidryk nie ongesiens verbygegaan nie. Godsdienstige nadenke in die Noordryk het die unieke omstandighede daar weerspieël en ' $n$ baie besondere boodskap oor God en sy betrokkenheid by die mense en die natuur geformuleer.

Aan die Noordrykse teologie het ons konsepte soos die uniekheid van God, sosiale geregtigheid as ' $n$ eis van God aan maghebbers én gewone mense en die begrip van Jahwe as God van die geskiedenis én die natuur te danke.

\section{Literatuurverwysings}

Avigad, N 1993. Samaria (City), in: Stern, E (ed), The new encyclopedia of archaeological excavations in the Holy Land, 1300-1310. Jerusalem: IES and Carta.

Boshoff, W S 1992. Yahweh as God of nature: Elements of the concept of God in the book of Hosea. JNSL 18,13-24.

-, 1994a. Die boek Hosea en die Jahwe-Baäl-stryd. Ongepubliseerde DD-proefskrif. Universiteit van Pretoria.

-, 1994b. Sexual encounters of a different kind: Hosea 1:2 as foreplay to the message of the book Hosea. Religion and Theology 1,329-339.

-, 1997. Denkbeelde oor God by Hosea. Skrif en Kerk 18(1)1997, 1-21.

-, 2000. Jeroboam ben Nebat in the Deuteronomistic History, in: De Moor, J C \& Van Rooy, H F (eds), Past, present, future: The Deuteronomistic History and the prophets, 19-35. Leiden: Brill. 
-, (in druk). Who let grain, grapes and olives grow? Hosea's polemics against the Yahwists of Israel, in: Van der Toorn, A (ed), Religious polemics in context, Leiderdorp: Deo Publishing.

Boshoff, W S, Scheffler, E H \& Spangenberg, I J J 2000. Ancient Israelite literature in context. Pretoria: Protea.

Burkitt, F C 1926. Micah 6 and 7 a Northern prophecy. JBL 45,159-161.

Deist, F E 1991. ' $n$ Veesmous preek in Samaria. Pretoria: Van Schaik.

Deist, F E \& Le Roux J H 1987. Rewolusie en reïnterpretasie: Hoofstukke uit die geskiedenis van Israel. Kaapstad: Tafelberg (Die literatuur van die Ou Testament 4).

Donner, H 1977. The separate states of Israel and Judah, in: Hayes, J H \& Miller, J M (eds), Israelite and Judaean history, 381-434. London: SCM.

Eissfeldt, O 1964. Einleitung in das Alte Testament. 3.Aufl. Tübingen: Mohr (Paul Siebeck).

Fohrer, G 1968. Introduction to the Old Testament. $\left(10^{\text {th }}\right.$ ed of Ernst Sellin's Einleitung in das Alte Testament translated by David Green). London: SPCK.

Galil, G 1996. The chronology of the kings of Israel and Judah. New York: Brill.

Gottwald, N K 1985. The Hebrew Bible - A socio-literary introduction. Philadelphia: Fortress.

Jenks, A W 1977. The Elohist and North Israelite traditions. (SBLMS 22). Missoula: Scholars Press.

Kaiser, O 1984. Einleitung in das Alte Testament: Eine Einführung in ihre Ergebnisse und Probleme. 5.Aufl. Gütersloh: Gütersloher Verlagshaus Gerd Mohn.

Macintosh, A A 1997. A critical and exegetical commentary on Hosea. (ICC). Edinburgh: T\&T Clark.

Rendtorff, R 1983. Das Alte Testament: Eine Einführung. Neukirchen-Vluyn: Neukirchener Verlag.

Schoors, A 1998. Die Königreiche Israel und Juda im 8. und 7. Jahrhundert v. Chr.: Die Assyrische Krise. (Biblische Enzyklopädie Bd 5). Stuttgart: Kohlhammer.

Smelik, K A D 2000. The inscription of King Mesha, in Hallo, W W \& Younger, K $\mathrm{L}$ (eds), The context of Scripture vol 2: Monumental inscriptions from the biblical world, 137-138. Leiden: Brill.

Soggin, J A 1976. Introduction to the Old Testament: From its origins to the closing of the Alexandrian canon. London: SCM.

Stern, E 1993. The many masters of Dor, part 2: How bad was Ahab? BAR 19(2), 18-29.

Stern, E 2000. Dor: Ruler of the seas. Nineteen years of excavations at the IsraelitePhoenician harbor town on the Carmel coast. (Rev and expanded edition). Jerusalem: IES.

Strydom, J G 1988. Micah, Anti-Micah and Deutero-Micah: A critical discussion with A S van der Woude. Ongepubliseerde DTh-proefskrif, Universiteit van SuidAfrika. 
Uitgewer en redakteurs, 1995. CUM Eenvolume-kommentaar: Opset, aard en redaksionele beleid. Ongepubliseerde brief aan medewerkers van Die Bybellennium.

Uitgewer en redakteurs, 1997. Eenvolumekommentaar. Ongepubliseerde brief aan medewerkers van Die Bybellennium.

Van der Woude, A S 1977. Micha. 2e druk. Nijkerk: Callenbach. (POT).

Von Rad, G 1966. Deuteronomy: A commentary. (OTL). London: SCM

Vosloo, W 1989. Méér as net 'n storie. 2e Uitg. Pretoria: N G Kerkboekhandel.

-, 1992. Die samestelling en struktuur van die boek Hosea. Skrif en Kerk 13(2) 1992, 244-252.

-, [s j]. Verklaring van Hosea 11. Bybelkunde 310. Pretoria: Universiteit van Pretoria.

Vosloo, W \& Van Rensburg, F J (reds) 1993. Die Bybel in praktyk. Vereeniging: CUM.

-, 1999. Die Bybellennium eenvolumekommentaar: Die Bybel uitgelê vir eietydse toepassing. Vereeniging: CUM.

Wolff, H W 1965. Dodekapropheton 1: Hosea. (BKAT XVI/1). Neukirchen-Vluyn: Neukirchener Verlag.

-, 1969. Dodekapropheton 2: Joel und Amos. (BKAT XVI/2). Neukirchen-Vluyn: Neukirchener Verlag.

Yee, G A 1987. Composition and tradition in the book of Hosea: A redaction critical investgation. Atlanta, GA: Scholars Press. (SBLDS 102). 